\title{
KEBIJAKAN HUKUM PENATAAN RUANG KAWASAN HUTAN YANG BERKEPASTIAN HUKUM DI PROVINSI RIAU
}

\author{
Dede Mirza \\ Sekretarial Daerah Kota Dumai \\ e-mail: dedemirza1203@gmail.com
}

\begin{abstract}
Abstrak-Dengan telah diterbitkannya UU No. 26 Tahun 2007 tentang Penataan Ruang, maka semua peraturan daerah provinsi tentang rencana tata ruang wilayah provinsi harus disesuaikan paling lambat dalam waktu 2 (dua) tahun terhitung sejak undang-undang diberlakukan. Penataan ruang kawasan hutan dilakukan dalam rangka revisi Perda RTRWP untuk mengoptimalkan pemanfaatan ruang agar terwujud ruang yang aman, nyaman, produktif dan berkelanjutan. Di Provinsi Riau, proses revisi RTRWP belum selesai sesuai dengan waktu yang telah ditetapkan. Perlu adanya kebijakan hukum penataan ruang kawasan hutan dalam rangka revisi RTRWP di Indonesia dan rekonstruksi regulasi kebijakan hukum penataan ruang kawasan hutan dalam rangka revisi RTRWP menuju kawasan hutan yang berkepastian hukum di Provinsi Riau. Penelitian ini merupakan penelitian hukum normatif dan menggunakan 2 (dua) pendekatan, yaitu pendekatan peraturan perundang-undangan dan pendekatan konseptual. Sebagian besar data diperoleh melalui studi pustaka dan dilengkapi dengan studi lapangan, lalu dianalisa secara deskriptif.
\end{abstract}

\section{Kata Kunci: Kebijakan Hukum, Penataan Ruang Kawasan Hutan, dan Kepastian Hukum.}

\begin{abstract}
With the law number 26 Year 2007 on Spatial Planning, all provincial regulations on provincial spatial plans should be adjusted no later than 2 (two) years after the law is enacted. Spatial arrangement of forest area is done in Provincial Spatial Planning Law to optimize the utilization of space in order to realize a safe, comfortable, productive and sustainable space. In Riau Province, the revision of the provincial spatial plan has not been completed in accordance with the stipulated time. The formulation of the problem in this Dissertation is how the legal policy of spatial planning of forest area in the framework of revision of RTRWP in Indonesia, and how to reconstruct regulation of law policy of spatial arrangement of forest area in the framework of revision of provincial spatial plan to legal forest area in Riau Province. This research is normative research and use two approach, that is approach of legislation and conceptual approach. Most of the data was obtained through literature study and completed with field study, then analyzed descriptively.
\end{abstract}

Keywords: The Legal Policy, Spatial, Forest Areas, and Legal Certainly.

\section{A. PENDAHULUAN}

Sesungguhnya dalam penciptaan langit dan bumi, silih bergantinya malam dan siang, bahtera yang berlayar di laut membawa apa yang berguna bagi manusia dan apa yang Allah turunkan dari langit berupa air, lalu dengan air itu dia hidupkan bumi sesudah mati (kering)nya dan Dia sebarkan di bumi itu 
segala jenis hewan dan pengisaran angin dan awan yang dikendalikan antara langit dan bumi: sungguh (terdapatlah) tanda-tanda (keesaan dan kebesaran Allah) bagi kaum yang memikirkannya (Q.S. Al-Baqarah: 164). Salah satu ciptaan-Nya yang wajib disyukuri adalah Hutan.

Luas kawasan hutan di Indonesia tercatat jumlahnya kurang lebih 136,88 juta hektar, termasuk kawasan konservasi perairan. Sebagai negara yang terletak pada kawasan tropis dunia, hutan Indonesia terdiri dari 15 formasi hutan dan sebagian besar didominasi oleh tipe hutan hujan tropis. Hutan tropis Indonesia dikenal sebagai tempat megadiversity sehingga menjadi pusat konsentrasi keragaman hayati, baik di daratan maupun perairan (Kementerian

Kehutanan, 2010-2014:4).

Sejalan dengan Pasal 33 UUD 1945 sebagai landasan konstitusional yang mewajibkan agar bumi, air dan kekayaan alam yang terkandung di dalamnya dikuasai oleh Negara dan dipergunakan untuk sebesar-besar kemakmuran rakyat, maka penyelenggaraan kehutanan senantiasa mengandung jiwa dan semangat kerakyatan, berkeadilan dan berkelanjutan. Oleh karena itu penyelenggaraan kehutanan harus dilakukan dengan asas manfaat dan lestari, kerakyatan, keadilan, kebersamaan, keterbukaan dan keterpaduan dengan dilandasi akhlak mulia dan bertanggung-gugat.

Keberadaan kawasan hutan dalam suatu wilayah merupakan bagian dari ruang wilayah provinsi maupun kabupaten/kota yang bersangkutan sehingga kebijakan penataan ruang wilayah provinsi dan kabupaten/kota akan memberikan implikasi luas terhadap keberadaan kawasan hutan tersebut. Pencapaian keselarasan pemanfaatan ruang yang berkelanjutan memerlukan suatu arahan berupa kebijakan penataan ruang yang bersifat nasional dan wajib untuk diterapkan dalam bentuk peraturan perundang-undangan nasional maupun perjanjian atau konvesi internasional yang bersifat mengikat (Epi Syahadat dan Subarudi, 2012:131).

Padahal efektifitas hukum akan terwujud apabila sistem hukum yang terdiri dari unsur struktur hukum, substansi hukum dan kultur hukum 
bekerja saling mendukung di dalam pelaksanaannya, sehingga dapat memenuhi tujuan hukum yang diharapkan semua pihak (Muchtar Wahid, 2008:81).

Walaupun demikian, berbagai langkah startegis untuk mengatasi permasalahan tersebut di atas telah dilakukan oleh Pemerintah. Berkaitan dengan kawasan hutan Pemerintah mengeluarkan 2 (dua) regulasi penting berkaitan dengan masa depan kawasan hutan di Indonesia. Kedua regulasi tersebut adalah Pertama PP No. 104 Tahun 2015 tentang Tata Cara Perubahan Peruntukan dan Fungsi Kawasan Hutan . Kedua, Peraturan Pemerintah No. 61 Tahun 2012 tentang Perubahan Atas Peraturan Pemerintah No. 24 Tahun 2010 tentang Penggunaan Kawasan Hutan.

Soal kepastian hukum di dalam Pasal 14 dan 15 dijelaskan bahwa yang memberikan kepastian hukum atas kawasan hutan adalah kegiatan pengukuhan kawasan hutan. Kegiatan pengukuhan kawasan hutan itu meliputi empat tahap, yaitu:

1. Penunjukan kawasan hutan;

2. Penataan batas kawasan hutan;

3. Pemetaan kawasan hutan; dan
4. Penetapan kawasan hutan.

Berdasarkan issue strategis bidang kehutanan dalam penataan ruang dan pertanahan, terdapat (1) belum terselesaikannya penetapan kawasan hutan di beberapa daerah; (2) skala peta yang tidak terinci kebanyakan menggunakan skala 1:100.000 atau 1: 250.000 dan tersedia paling rinci beberapa menggunakan skala $1: 50.000$ (tr@bappenas.go.ig/www.trp.or.id).

Konflik kepentingan antarsektor seperti kehutanan menjadi kendala dalam revisi RTRWP. Sampai saat ini, terdapat 8 (delapan) provinsi yang belum menetapkan Peraturan Daerah RTRW.

Untuk permasalahan yang dikaji dalam tahun kedua lebih difokuskan pada permasalahan Bagaimana kebijakan hukum penataan ruang kawasan hutan dalam rangka revisi rencana RTRWP di Indonesia dan Bagaimana rekonstruksi regulasi penataan ruang kawasan hutan dalam rangka revisi RTRWP menuju kawasan hutan yang berkepastian hukum di Provinsi Riau.

\section{B. HASIL DAN PEMBAHASAN}


1. Kebijakan Hukum Penataan Ruang Kawasan Hukum Dalam Revisi RTRWP Di Indonesia

Pengelolaan hutan di Indonesia sejak masa kemerdekaan secara umum diatur dalam UUD 1945 yang dalam pasal 33 ayat (2) menyatakan: "cabang-cabang produksi yang penting bagi negara dan menyangkut hajat hidup orang banyak dikuasai oleh negara". Kemudian dalam ayat (3) dinyatakan bahwa: bumi, air, dan kekayaan yang terkandung di dalamnya dikuasai oleh negara dan dipergunakan untuk sebesar-besar kemakmuran rakyat. Salah satu kekayaan alam yang sudah dimanfaatkan sejak masa pemerintahan kolonial Hindia Belanda adalah hutan dan hasil hutan. Pengaturan lebih lanjut terhadap hutan ini sebagaimana dinyatakan dalam ayat (5) yaitu dengan Undangundang, yakni melalui UU No. 5 Tahun 1967 yang diganti dengan UU No. 41 Tahun 1999 tentang Kehutanan, sebagaimana telah diubah dengan UU No. 19 Tahun 2004 tentang Penetapan Peraturan Pemerintah Pengganti No. 1 Tahun
2004 tentang Perubahan Atas UU No. 41 Tahun 1999 tentang Kehutanan. Selain itu, pengaturan tentang hutan juga diatur dalam beberapa Undangundang lain, yaitu: UU No. 5 Tahun 1990 tentang Konservasi Sumberdaya Hayati dan Ekosistemnya, UU No. 26 Tahun 2007 tentang Penataan Ruang, UU No. 32 Tahun 2009 tentang Pengelolaan Lingkungan Hidup dan UU No. 18 Tahun 2013 tentang Pencegahan dan Pemberantasan Perusakan Hutan.

Pembangunan kehutanan Indonesia didasarkan pada mandat UU No. 41 Tahun 1999, yang merupakan pengganti UU No. 5 Tahun 1967, dan UU No. 5 Tahun 1990 yang mendefinisikan kehutanan sebagai sistem pengurusan yang bersangkut paut dengan hutan, kawasan hutan, dan hasil hutan yang diselenggarakan secara terpadu. Undang-undang tersebut juga memberikan mandat penguasaan hutan oleh Negara yang memberi wewenang kepada pemerintah untuk:

a. Mengatur dan mengurus segala sesuatu yang berkaitan dengan hutan, kawasan hutan, dan hasil hutan. Dalam konteks ini, pembangunan kehutanan diselenggarakan melalui empat 
dimensi pengurusan hutan, yaitu: (1) perencanaan kehutanan; (2) pengelolaan hutan; (3) penelitian dan pengembangan, pendidikan dan pelatihan, serta penyuluhan; dan (4) pengawasan dan pengendalian.

b. Menetapkan status wilayah tertentu sebagai kawasan hutan atau kawasan hutan sebagai bukan kawasan hutan.

c. Mengatur dan menetapkan hubungan-hubungan hukum antara orang dengan hutan, serta mengatur perbuatan-perbuatan hukum mengenai kehutanan.

Berdasarkan perkembangan pengukuhan kawasan sampai dengan April 2011, luas kawasan hutan dan perairan seluruh Indonesia adalah 130,68 juta ha. Menurut fungsinya kawasan tersebut terdiri dari Hutan Konservasi (HK) seluas 26,82 juta ha, Hutan Lindung (HL) seluas 28,86 juta ha, Hutan Produksi (HP) seluas 32,60 juta ha, Hutan Produksi Terbatas (HPT) seluas 24,46 juta ha, dan Hutan Produksi yang Dapat Dikonversi (HPK) seluas 17,94 juta ha. Total panjang batas kawasan hutan baik batas luar maupun batas antar fungsi mencapai 281.873 km. Sampai dengan tahun 2010, realisasi tata batas mencapai 74,67\% atau sekitar $222.452 \mathrm{~km}$ dan kawasan hutan yang telah ditetapkan seluas 14,24 juta ha
(Kementerian Kehutanan, 20112030).

Sedangkan penutupan lahan kawasan hutan Indonesia terdiri dari 41,26 juta ha hutan primer, 45,55 juta ha hutan sekunder, 2,82 juta ha hutan tanaman serta 41,05 juta ha merupakan areal yang tidak berhutan. Penutupan lahan berhutan terdapat juga di luar kawasan hutan/areal penggunaan lainnya yaitu seluas sekitar 8,07 juta hektar yang potensial dijadikan penunjang industri kehutanan baik yang berbasis kayu maupun non kayu (Kementerian Kehutanan, 20112030).

2. Rekonstruksi Terhadap UU No. 41 Tahun 1999 Tentang Kehutanan Melalui Aspek Substansi Hukum, Struktur Hukum dan Budaya Hukum

Pengertian rekonstruksi (reconstruction) menurut Black's Law Dictionary diartikan sebagai the act or process of re-building, re-creating, or re-organizing something (Bryan A. Garner, 1999:1278). Dari pengertian tersebut rekonstruksi diartikan sebagai kegiatan atau proses 
untuk membangun kembali/ menciptaan kembali/ melakukan pengorganisasian kembali atas sesuatu. Dalam konteks hukum, maka rekonstruksi hukum berarti sebagai proses untuk membangun kembali hukum. Apabila rekonstruksi dikaitkan dengan konsep atau gagasan atau ide tentang hukum berarti rekonstruksi hukum dimaknai sebagai suatu proses untuk membangun kembali atau menata ulang gagasan, ide atau konsep tentang hukum dalam kaitannya dengan regulasi penyelenggaraan penataan ruang kawasan hutan.

Secara normatif-positivistik, penyelenggaraan kehutanan telah dituangkan dalam UU No. 41 Tahun 1999 tentang Kehutanan. Dalam ketentuan Pasal 3 disebutkan bahwa penyelenggaraan kehutanan bertujuan untuk sebesar-besar kemakmuran rakyat yang berkeadilan dan berkelanjutan dengan:

a. menjamin keberadaan hutan dengan luasan yang cukup dan sebaran yang proporsional;

b. mengoptimalkan aneka fungsi hutan yang meliputi fungsi konservasi, fungsi lindung, dan fungsi produksi untuk mencapai manfaat lingkungan, sosial, budaya, dan ekonomi, yang seimbang dan lestari;

c. meningkatkan daya dukung daerah aliran sungai;

d. meningkatkan kemampuan untuk mengembangkan kapasitas dan keberdayaan masyarakat secara partisipatif, berkeadilan, dan berwawasan lingkungan sehingga mampu menciptakan ketahanan sosial dan ekonomi serta ketahanan terhadap akibat perubahan eksternal; dan

e. menjamin distribusi manfaat yang berkeadilan dan berkelanjutan.

Proses penyusunan RTRW Provinsi Riau telah dimulai sejak tahun 1991, dengan kegiatan Penyusunan Awal RTRWP Riau. Selanjutnya pada tahun 1994 telah disahkan sebagai Perda No. 10 Tahun 1994 tanpa melalui proses paduserasi dengan TGHK. Kemudian pada tahun 2000 sampai dengan terjadi Revisi I terkait substansi UU No. 24 Tahun 1992 dan Pemekaran Wilayah Kabupaten/Kota di Provinsi Riau dan tahun 2004 terjadi Revisi II terkait Pemekaran Wilayah Provinsi Kepulauan Riau. Pada tahun 2008 dilakukan Penyesuaian substansi UU No. 26 Tahun 2007, PP No. 26 Tahun 2008.

Proses Awal Paduserasi di Kementerian Kehutanan dan pada 
tahun 2011 telah memasuki Tahap finalisasi di Kementerian Kehutanan RI dan Evaluasi substansi di Kementerian PU RI. Selanjutnya memasuki tahun 2012 merupakan tahapan penyelesaian RTRW Provinsi Riau, dimana saat ini draft RTRW Provinsi Riau, menunggu persetujuan substansi di Kementerian Pekerjaan Umum RI (BKPRN) dan persetujuan substansi di Kementerian Kehutanan RI (paduserasi kawasan hutan), untuk selanjutnya dilakukan evaluasi terhadap Ranperda RTRW Provinsi Riau di Kementerian Dalam Negeri RI. Hasil akhir evaluasi tersebut sebagai bahan dalam penetapan Peraturan Daerah tentang RTRW Provinsi Riau, setelah melalui pembahasan Ranperda RTRW Provinsi Riau di DPRD Provinsi Riau.

Substansi yang menjadi pembahasan dalam paduserasi pola ruang TGHK dan RTRWP Riau, adalah sebagai berikut:

a. Usulan Perubahan Peruntukan Kawasan Hutan (dari Kawasan Hutan menjadi Non Hutan (APL) dengan usulan/GAP lebih kurang 3,5 juta $\mathrm{Ha}$ );

b. Usulan Perubahan Fungsi Kawasan Hutan (misal dari Hutan
Produksi (HP) menjadi Hutan Produksi yang dapat dikonversi (HPK), dan seterusnya dengan usulan lebih kurang 513.000 Ha).

Pada tanggal 20 Oktober 2008 Gubernur Riau melakukan ekspose usulan perubahan kawasan hutan yang ditindaklanjuti dengan surat usulan Nomor: 050/Bappeda/56.10 tanggal 27 April 2009, dan terjadi dua kali revisi usulan revisi pertama melalui Surat Gubernur Riau Nomor: 050/Bappeda/65.27.a tanggal 30 November 2009 dan revisi kedua melalui Surat Gubernur Riau No. 050/Bappeda/76.03 tanggal 09 Februari 2010.

Sebagai Tindaklanjut Menteri Kehutanan membentuk Tim Terpadu melalui Keputusan Menhut No. 410/ Menhut-VII/2009 tanggal 7 Juli 2009 dan Direktur Jenderal Planologi Kehutanan membentuk Tim Teknis melalui Keputusan No. SK.12/VIIREN/2009 tanggal 14 Mei 2009.

Dalam Rangka Revisi RTRWP Riau, Tim Terpadu merekomendasi perubahan kawasan hutan (Keputusan Menhut No.410/Menhut-VII/2009), sebagai berikut: 
a. Perubahan peruntukan Kawasan Hutan seluas \pm 2.740 .586 ha, yang terdiri dari:

1) $\pm 154.065 \mathrm{Ha}$ merupakan perubahan peruntukan yang DPCLS yang memerlukan persetujuan DPR-RI.

2) $\pm 2.586 .521 \mathrm{Ha}$ merupakan perubahan peruntukan yang tidak DPCLS.

b. Perubahan fungsi seluas \pm 709.184 Ha.

c. Penambahan kawasan hutan seluas $\pm 13.685 \mathrm{Ha}$.

\section{Pada tanggal 29 September}

2014 Kementerian Kehutanan mengeluarkan Keputusan Menteri Kehutanan RI No. SK. 878/MenhutII/2014 Tentang Kawasan Hutan Provinsi Riau, berdasarkan SK tersebut, Kawasan Hutan Propinsi Riau seluas \pm 5.499 .693 (lima juta empat ratus sembilan puluh sembilan ribu enam ratus sembilan puluh tiga) hektar, yang dirinci menurut fungsi dengan luas sebagai berikut:

a. Kawasan Suaka Alam (KSA)/ Kawasan Pelestarian Alam (KPA)/ Taman Buru, seluas \pm 633.420 (enam ratus tiga puluh tiga ribu empat ratus dua puluh) hektar;

b. Kawasan Hutan Lindung, seluas \pm 234.015 (dua ratus tiga puluh empat ribu lima belas) hektar;

c. Kawasan Hutan Produksi Terbatas (HPT), seluas \pm 1.031 .600 (satu juta tiga puluh satu ribu enam ratus) hektar; d. Kawasan Hutan Produksi Tetap (HP), seluas \pm 2.331 .891 (dua juta tiga ratus tiga puluh satu ribu delapan ratus sembilan puluh satu) hektar;

e. Kawasan Hutan Produksi yang dapat dikonversi (HPK), seluas \pm 1.268.767 (satu juta dua ratus enam puluh delapan ribu tujuh ratus enam puluh tujuh) hektar.

Berdasarkan Peraturan Daerah Provinsi Riau Nomor 10 Tahun 1994 tentang Rencana Tata Ruang Wilayah (RTRW) Provinsi Riau yang saat ini dalam proses penyempurnaan, perwujudan tata ruang wilayah mengindikasikan adanya disparitas perkembangan dan pembangunan antara wilayah Riau bagian Utara, Tengah dengan Selatan; antara kawasan perkotaan dengan pedesaan; antara kawasan pantai timur dengan kawasan barat. Wujud kesenjangan tata ruang wilayah tersebut antara lain karena belum berfungsinya pusatpusat pertumbuhan yang belum berkembang secara hirarkis serta kesenjangan penyediaan sarana dan prasarana wilayah.

Permasalahan konflik pemanfaatan ruang tercatat di sebagian besar wilayah Provinsi Riau terutama berkaitan dengan tumpang tindih fungsi ruang, perbedaan 
kepentingan atas bidang lahan, dan pemanfaatan lahan secara liar. Pemanfaatan ruang darat dan laut yang berfungsi lindung untuk kegiatan budidaya memberikan dampak berupa kerusakan dan penurunan kualitas lingkungan. Pada masa mendatang pemanfaatan ruang perlu diselaraskan dengan ketetapan yang diatur dalam Rencana Tata Ruang Wilayah (RTRW) Provinsi Riau, terutama dalam upaya mempertahankan, menjaga dan melestarikan kawasan yang berfungsi lindung, baik suaka alam, perlindungan daerah bawahan, perlindungan setempat, kawasan rawan bencana alam, kawasan bergambut dan berhutan mangrove dan kawasan terumbu karang dan padang lamun.

Bertolak dari prinsip-prinsip dasar tersebut, kalangan pembuat kebijakan penataan ruang kawasan hutan akan secara sungguh-sungguh memperhatikan dan mempertimbangkan berbagai kepentingan yang tercakup dalam sebuah ruang sosial. Kepentingankepentingan yang dimaksudkan di sini adalah aspek-aspek yang berhubungan dengan kepentingan daerah yang berada dalam ruang sosial tersebut, aspek-aspek yang berhubungan dengan masalah lingkungan ekologis (pelestarian, pengelolaan, pemanfaatan, dan sebagainya), dan aspek-aspek yang berhubungan dengan masalah kepastian hukum kawasan hutan sebuah ruang sosial.

Pertama, mengenai aspek substansi dalam rekonstruksi kebijakan hukum penataan ruang kawasan hutan. Dalam merekonstruksi sebuah kebijakan hukum penataan ruang kawasan hutan yang berkepastian hukum diharapkan berlangsung dalam sebuah proses yang bersifat akomodatif-responsif, hukum yang sifatnya dapat menyelesaikan pertentangan yang ada, tidak kaku, keterbukaan dan fleksibilitas.

Kedua aspek struktur hukum dalam sistem hukum menunjuk pada unsur-unsur yang terlibat dalam penataan ruang kawasan hutan. Hutan sebagai karunia dan amanah Tuhan Yang Maha Esa yang dianugerahkan kepada Bangsa Indonesia, merupakan kekayaan yang dikuasai oleh Negara, 
memberikan manfaat serbaguna bagi umat manusia, karenanya wajib disyukuri, diurus, dan dimanfaatkan secara optimal, serta dijaga kelestariannya untuk sebesar-besar kemakmuran rakyat, bagi generasi sekarang maupun generasi mendatang.

Ketiga, mengenai aspek budaya hukum dalam melakukan rekonstruksi kebijakan penataan ruang kawasan hutan. Aspek budaya hukum ini juga menjadi sangat penting untuk dipertimbangkan dalam melakukan rekonstruksi kebijakan penataan ruang kawasan hutan, karena kalau tidak demikian halnya maka segala aktivitas penataan ruang kawasan hutan akan cenderung merusak tatanan nilai budaya yang dimiliki oleh masyarakat.

\section{SIMPULAN}

1. Kebijakan hukum penataan ruang kawasan hutan dalam rangka revisi RTRWP di Indonesia baik pada landasan filosofis, landasan yuridis, dan landasan sosiologis, telah diatur dengan jelas, baik dalam hukum dasar (konstitusi), seperti telah diatur dalam UUD Negara Kesatuan Republik Indonesia Tahun 1945, maupun dalam hukum instrumental, seperti diatur dalam berbagai UU dan ataupun dalam hukum praktis seperti Peraturan Pemerintah, Peraturan Presiden, Peraturan Daerah dan peraturan yang lebih rendah lainnya.

2. Rekonstruksi kebijakan hukum penataan ruang kawasan hutan Provinsi Riau dilakukan dengan memperhatikan 3 (tiga) aspek yaitu:

a. Substansi hukum, dalam melakukan rekonstruksi kebijakan penataan ruang kawasan hutan diharapkan berlangsung perlu adanya peraturan perundangundangan yang bersifat akomodatif-responsif.

b. Struktur hukum; dalam pembuatan melakukan rekonstruksi kebijakan penataan ruang kawasan hutan diharapkan berlangsung dalam sebuah proses yang bersifat relasional-kolektif antara 


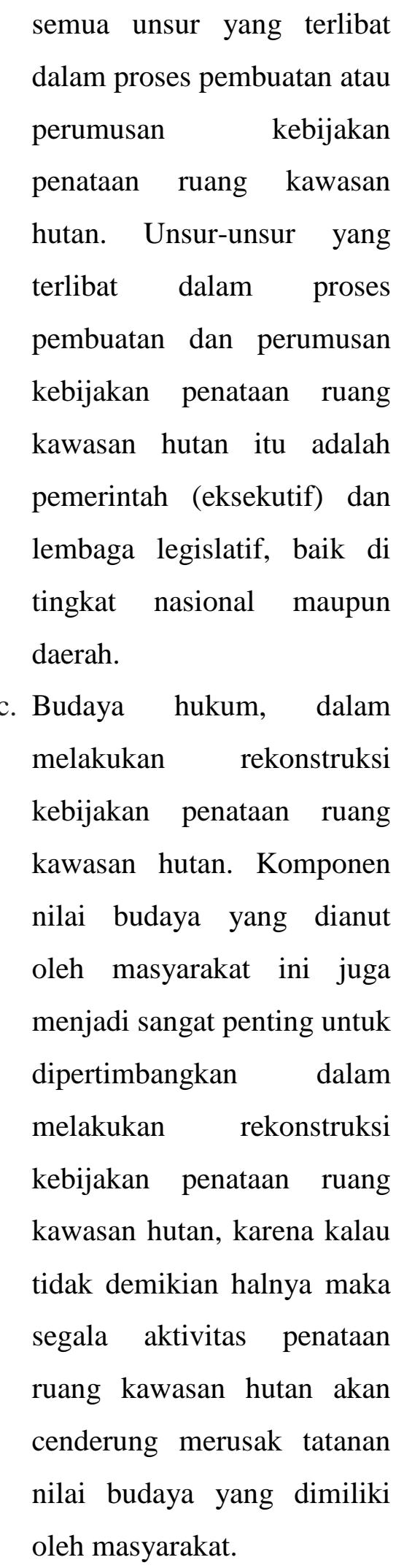

\section{SARAN}

1. Kementerian Kehutanan dan Lingkungan Hidup sebagai otoritas tertinggi dalam pemanfaatan kawasan hutan untuk mengeluarkan Peraturan Menteri Kehutanan tentang Percepatan Pengukuhan Kawasan Hutan serta melakukan kajian harmonisasi peraturan perundang-perundangan tentang penataan ruang kawasan hutan. Harmonisasi peraturan perundang-undangan baik vertikal maupun horisontal dengan peraturan yang terkait. Demikian juga harmonisasi aturan hukum tidak tertulis dengan aturan hukum lainnya. Harmonisasi ini diharapkan mempercepat pengukuhan kawasan hutan dan berguna bagi penataan ruang kawasan hutan yang lebih berhasil guna bagi kemakmuran masyarakat.

2. Untuk mewujudkan penataan ruang kawasan hutan yang berkepastian hukum di Provinsi Riau, perlu adanya:

a. Substansi hukum, apabila prinsip akomodatif-responsif dilaksanakan dalam aturan hukum, maka yang 
pantas untuk dibangun di masa depan adalah hukum yang berpihak kepada martabat manusia, biofisik (ekosistem) dan demokratis, karena itu substasi hukum tidak boleh memiliki potensi menguntungkan satu kelompok tertentu, siapapun orangnya. Harus pula dicegah terbentuknya substansi hukum yang bersifat koruptif.

b. Struktur hukum, apabila prinsip relasional-kolektivitas

dikembangkan dalam pola pembuatan kebijakan penataan ruang kawasan hutan, maka perlu ditumbuhkan budaya kerjasama di antara sesama pengambil kebijakan agar perlu mengurangi atau meniadakan sama sekali dikotomi antara kelompok adanya kekuatan politik, melainkan secara bersama-sama memikirkan nasib masyarakat yang terakomodir dalam kebijakan penataan ruang tersebut. Oleh karena itu, perlu ada arahan yuridis yang jelas mengatur tentang pola kerjasama di antara para pengambil kebijakan agar tidak ada peluang untuk saling mendominasi dan saling menegasi (meniadakan) satu dengan yang lain.

c. Budaya hukum, pola pembuatan kebijakan penataan ruang kawasan hutan harus mengutamakan hakhak rakyat setempat. Dalam konteks penataan ruang kawasan hutan hendaknya diarahkan pada pengutamaan masyarakat atau rakyat desa atau dikenal dengan keariban lokal.

\section{DAFTAR PUSTAKA}

Al-Quran Surah Al-Baqarah.

Bryan A. Garner, Black's Law Dictionary, Edisi ke-7, West Group,S.T. Paul. Minn, 1999.

Epi Syahadat dan Subarudi, Permasalahan Penataan Ruang Kawasan Hutan Dalam Rangka Revisi Rencana Tata Ruang Wilayah Provinsi, Jurnal Analisis Kebijakan Kehutanan Vol. 9 No. 2, Agustus 2012.

Kementerian Kehutanan, Rencana Kehutanan Tingkat Nasional (RKTN) Tahun 2011-2030.

Kementerian Kehutanan, Rencana Strategis 2010-2014, (Peraturan Menteri Kehutanan Republik Indonesia No: P.08/MenhutII/2010 Tentang Rencana Strategis (RENSTRA) Kementerian Kehutanan Tahun 2010-2014).

Keputusan Menhut No. 410/ MenhutVII/2009. 
Dede Mirza, Kebijakan Hukum Penataan Ruang Kawasan Hutan...

Muchtar Wahid, Memaknai Kepastian Hukum Hak Milik Atas Tanah, Suatu Analisis Dengan Pendekatan Terpadu Secara Normatif dan Sosiologis, Republika, Jakarta, 2008.

Presentasi "Direktur TataRuang dan Pertanahan Kementerian
Perencanaan Pembangunan Nasional/Badan Perencanaan Pembangunan Nasional Permasalahan Penetapan Kawasan Hutan Dalam Penataan Ruang dan Pertanahan Nasional', Jakarta 20 Agustus 2014. 